Cahiers $d u$ MONDE RUSSE

\section{Cahiers du monde russe}

Russie - Empire russe - Union soviétique et États indépendants

$52 / 4 \mid 2011$

Varia

\title{
I.V. Kurukin, A.B. Plotnikov, 19 janvarja - 25 fevralja 1730 goda
}

\section{Dmitry Redin}

Maureen Perrie (ed.)

Translator. Olga Ermakova

\section{(2) OpenEdition}

\section{Journals}

\section{Electronic version}

URL: http://journals.openedition.org/monderusse/7570

DOI: $10.4000 /$ monderusse. 7570

ISSN: $1777-5388$

\section{Publisher}

Éditions de l'EHESS

\section{Printed version}

Date of publication: 20 December 2011

Number of pages: $670-674$

ISBN: 978-2-7132-2353-2

ISSN: $1252-6576$

\section{Electronic reference}

Dmitry Redin, «I.V. Kurukin, A.B. Plotnikov, 19 janvarja - 25 fevralja 1730 goda », Cahiers du monde russe [Online], 52/4 | 2011, Online since 09 September 2013, Connection on 22 September 2020. URL : http://journals.openedition.org/monderusse/7570; DOI : https://doi.org/10.4000/monderusse.7570

This text was automatically generated on 22 September 2020

(c) École des hautes études en sciences sociales 


\title{
I.V. Kurukin, A.B. Plotnikov, 19 janvarja - 25 fevralja 1730 goda
}

\author{
Dmitry Redin
}

Maureen Perrie (ed.)

Translation : Olga Ermakova

\section{REFERENCES}

I.V. Kurukin, A.B. Plotnikov, 19 janvarja - 25 fevralja 1730 goda: Sobytija, ljudi, dokumenty [January $19^{\text {th }}-$ February $25^{\text {th }} 1730$ : events, people, documents]. Moscow : Kvadriga, Ob"edinennaja redakcija MVD Rossii, 2010, 280 p.

What happened in Russia in January-February 1730? It is absolutely clear that neither for the readers nor for the authors is the issue simply one of reconstructing the course of events. The attempt by a group of imperial dignitaries to establish a limited monarchical regime during the interregnum; the difficult and in many ways enforced dialogue between the verkhovniki (the members of the Supreme Privy Council) and the shljakhetstvo (the nobility); the short but extraordinarily strong outburst of political creativity displayed by various groups of the nobility; and finally, the collapse of the "intrigue" and the restoration of autocratic power - all of this is basic textbook-level information. But the questions which inevitably follow from our acquaintance with the events described are very complicated; so too is the evaluation of these events, owing to the importance and significance of what happened. For at no later time, in the entire course of Russian imperial history, was there a more radical and realizable (that's why we will leave "Decembrism" out of the equation) encroachment on the sovereign rights of the monarch. The authors note that "within five weeks the imperial power established by Peter I was significantly limited, and in another 'configuration' of political forces these limitations could have become an important factor in the future course of Russian history" (p. 5). In my own view they did to a certain extent become such a factor, bearing in mind the impact of these limitations on the subsequent sociopolitical thought of the Russian elite and therefore on the political life of the country. 
2 Almost all students of the short period of the interregnum in 1730 have tried in various ways to interpret the attempt of the in the context of the whole course of the national political experience. But, as we can see from the detailed and comprehensive historiographical research of Kurukin and Plotnikov (p. 7-24), no common conceptual evaluation has yet been formed. Questions were formulated and became established in the literature, and the differences between authors' interpretations, from Tatishchev to the present day, depended on their combinations of the answers to these questions. Who were the verkhovniki? The bearers of constitutional ideas, or dignitaries who tried to impose an oligarchic form of governance according to the interests of the old boyar families? What did their political demarche potentially involve? The chance of another course of development for Russia or the realization of the ideals of a "party" for the restoration of the pre-Petrine order? What did the shljakhetstvo that took part in the events in 1730 represent: a homogeneous autocratic opposition or an internally heterogeneous milieu displaying "constitutionalist" and "reactionary" wings? Is it possible to consider the nobles' actions as an indicator of a new qualitative stage of development of the national political culture, and of the growth of the social and political maturity of the service class? Or was their behavior no more than momentary risk-taking, explained by their patron-client relationships with the "powerful people"? Was the nobles' ultimate preference for autocratic government a sign of their stagnant and reactionary character, or an indication of their loyalty to the "precepts of Peter the Great"? The study and interpretation of the role of the year 1730 in Russian history had reached an impasse in Soviet academic literature. According to the authors' conviction, this situation can be overcome only as a result of a reassessment of the existing interpretations, a new and detailed understanding of the positions of different groups of the shljakhetstvo, the identification of the level of the actors' political concepts and attitudes, and the utilization of new sources discovered by the authors (p. 29-30).

The achievement of the declared goals was a difficult process. Kurukin and Plotnikov had to begin it ab ovo - they created the first full academic publication of sources on the history of the events of early 1730, which includes both documents that have been already published, and new materials discovered by the authors. It consists of five blocks: 1) editions of the "conditions," documents of the Supreme Privy Council, and political projects of the shljakhetstvo and verkhovniki from fond no. 3 of the Russian State Archive of Ancient Acts (RGADA); 2) legislative acts of the Supreme Privy Council and Anna Ioannovna, which were published in the Complete Collection of Laws of the Russian Empire (Polnoe Sobranie Zakonov Rossiiskoi Imperii) and in the collections of the Imperial Russian Historical Society, supplemented by documents from fond no. 176 of RGADA; 3 ) an extensive number of documents created by the supreme and central state institutions, from the fonds of RGADA and the Russian State Military-Historical Archive (RGVIA); 4) diplomatic materials which have been fairly extensively, but not always satisfactorily, published in the collections of the Imperial Russian Historical Society, significantly supplemented with documents from RGADA; 5) private documents, personal correspondence and memoirs which were published in the $19^{\text {th }}-20^{\text {th }}$ centuries. These documents occupy half of the book, and if they do not entirely exhaust the source possibilities for the problem under investigation in terms of their scope and variety, they certainly come very close to doing so. It is valuable that, thanks to the collection of published documents, the reader has the opportunity to participate in the research, to substantially agree or polemicize with its conclusions and logic; such an opportunity is provided very seldom because of the traditional system of references to 
secondary and primary sources; and it undoubtedly, enhances the scholarly importance of the book.

4 In the main part of the book, in a minute, concise, capacious and at the same time highly readable style, the authors reveal the chronology of events, but more importantly the complicated interweaving of the ideas, positions and motives of the actions of all the individuals involved in the thick of political events of the winter of 1730. Kurukin and Plotnikov have managed to produce a very harmonious combination of textological approaches and prosopographical analysis. The results of the latter are reinforced by data on the service position, types of service, age characteristics, and the estate- and serf-possessions of the participants in the "project of the majority," which are compiled in tables and diagrams in the appendices. These create a multidimensional and distinctive collective portrait of the most active part of the Russian nobility, the basis of which was formed by middle-ranking veteran administrators, the generation of the reforms, and the "backbone" of the Empire created by Peter the Great.

5 The prosopographical reconstruction undertaken by Kurukin and Plotnikov made it entirely possible to reveal the main behavioral models of the noble groups and their internal horizontal ties, and it served as an important basis for the formation of the authors' conception of the events of 1730 . The authors' central thesis that 'the idea of the limitation of autocratic power arose directly inside the autocratic state apparatus" (p.113), is extremely convincing. It overcomes the labyrinth of interconnected and unilinear binary oppositions traditionally employed in the historiography ("oligarchs"/ constitutionalists, old aristocracy/new gentry, progressives/traditionalists, etc.). The authors suggest that one should look at the main participants in the events through the prism of the evolution of the Russian state apparatus which took place in the first third of the $18^{\text {th }}$ century. In spite of the "convulsive" character of the administrative changes of Peter the Great, in a very short time (in historical terms) there emerged in the country a certain stratum of the upper and central bureaucracy that realized (or had sensed) its ability to manage the state administration without the strong and integrating figure of the monarch. According to the authors, the fact that the bureaucratic apparatus of autocracy had acquired the features of a kind of "selfgoverning mechanism" had the potential to bring about Russia's transformation into a "non-autocratic" monarchy. This view provides a new explanation not only for the participation of different groups of nobility in the political movement, but also for the instability and heterogeneity of their positions. The shljakhetstvo, which was unexpectedly involved in deciding the Empire's fate, should also be considered primarily as a part of the bureaucracy (the authors' research makes this obvious) - the middle-level bureaucracy.

Like the verkhovniki, the middle-level administrators were both the agents and the "products" of the reforms, so they fully accepted both the aim of a "break with former tradition" and the necessity of having "legally more defined relations between rulers and subjects" (p. 115). Besides, for all of the participants in the events encluding the authors of the boldest projects, "the transformation of the state system by no means implied any changes in the social system" (p.113). Between the verkhovniki and a significant part of the shljakhetstvo (at least, before the arrival of Anna Ioannovna in Russia) there was no real divergence on the question of the limitation of the monarch's power. But there existed a misunderstanding about the bounds of this limitation. While 
the higher bureaucracy of the Empire, and groups of the noble shljakhetstvo related to it, were prepared for a "deliberate act of destruction of the autocracy" (p. 114), for many of the old "Petrine servitors," who had experienced the Northern War and the administrative reforms of the first quarter of the century, the elimination of subordination to state power, to which such a sharp and frank limitation of autocracy could lead, was unthinkable. In the last resort, this divergence proved fatal for the verkhovniki.

7 Examining the political situation of the winter of 1730 through the prism of the evolution of the state apparatus does not contradict the other well-known factors which influenced the course of events, like the disparate levels of political culture, the fragmentation of the Russian nobility and the personal ambitions of the verkhovniki. But the interpretation proposed by Kurukin and Plotnikov makes it possible at last to reject some historiographical cliches. First of all, the aristocratic affiliation of the majority of the verkhovniki did not make them the adherents of some reactionary forces, the leaders of a non-existent "old-Russian party." Secondly, it must be recognized that the influence of the notorious "Swedish models" or of the theoretical treatises of European authors about the forms of state system on the practical actions of the verkhovniki has been greatly exaggerated. Without denying the familiarity of A.I. Osterman with the state system of Sweden, or the acquaintance of Prince D.M. Golitsyn with the works of John Locke, the verkhovniki can hardly be depicted as followers of their ideas. Their actions were an immediate result of the Petrine reforms, of that new quality which the system of Russian statehood had acquired by the end of the first third of the $18^{\text {th }}$ century. Hence it, thirdly, follows that it is hardly right to call the members of the Supreme Privy Council of 1730 either "constitutionalist" or "oligarchic" gouvernment. Kurukin and Plotnikov offer the entirely correct and effective term "non-autocratic" monarchy for the form of state system which might have been established if the plans of the verkhovniki had been implemented; a monarchy which is legitimately headed by the upper bureaucracy. The authors consider that "the movement towards "nonautocratic' monarchy in Russia was forcibly interrupted" (p. 116), and this is, perhaps, the only point on which my opinion diverges, for it seems to me that despite the failure of the specific project of 1730 , Russian statehood subsequently developed in roughly this direction by the next century.

On the whole the conceptualization proposed by Kurukin and Plotnikov certainly enables us to see a way out of the historiographical impasse in the understanding of the political situation of the interregnum in 1730, and allows a fresh perspective on the actions of the members of the Supreme Privy Council as a starting point in the history of Russian "enlightened bureaucracy." 